\title{
Mites (Acari, Oribatida) of selected organic farms from the Kujawy-Pomerania Province
}

\author{
"Konrad Majtka, "** Radomir Graczyk, "*Hanna Szczukowska, * Jarosław Kowalski \\ University of Science and Technology, Bydgoszcz, "Department of Zoology and Landscape, \\ ${ }^{* *}$ Department of Ecology, Kordeckiego 20, 85-225 Bydgoszcz, Poland \\ e-mail: konradm@utp.edu.pl
}

\begin{abstract}
The experiment was carried out on 3 organic farms in the Kujawy-Pomerania Province in 5 different habitats to determine the number and species composition of mites. Ten replicate samples of $50 \mathrm{~cm}^{3}$ and $17 \mathrm{~cm}^{2}$ were collected in 2011 from 3 layers, so altogether 780 samples were collected. In total, 14 taxa of Oribatida were identified. The total number of mites and Oribatida significantly differed in the analyzed habitats. Tectocepheus velatus [Michael, 1880], Scheloribates laevigatus [C.L. Koch, 1835], Punctoribates punctum [C.L. Koch, 1839] and Eupelops occultus [C.L. Koch, 1835] were the most abundant oribatid mite species.
\end{abstract}

Key words: Acari, Oribatida, agroecosystem, organic farming, bioindication.

\section{Introduction}

Mites (Acari) are group of small arachnids, which is morphologically, ecologically and habitat diverse. Mites live in almost every habitat, including freshwater and sea water. However, most of mites occur in terrestrial ecosystems, especially in the soil. Soil saprophagic mites are the most abundant organisms of soil mesofauna. Usually, saphrofagic mites systematically belong to oribatid mites (Oribatida). Soil mites are observed mainly in a humus layer of soil and they increase the breakdown of the organic matter (Behan-Pelletier 1999; Boczek \& Błaszak 2005). Most of oribatid mites occur in forest, moor and meadow soil. Abundance and biodiversity of oribatid mites depend on humidity and availability of the organic matter in a habitat. Oribatid mites show clumped distribution in soil, both vertical and horizontal types. It estimates that biomass of oribatid mites constitutes, according to a habitat, approximately 5 to 15 percent of all animals. Most of oribatid mites live in surface layers of soil, but the depth of their occurrence depends on a habitat, a thickness of the litter, an availability and a type of humus (Niedbała 1980). Many species of oribatid mites are commonly used for environmental research of bioindication or biodiversity, especially in forest and agricultural ecosystems (Hagvar 1994; Siepel 1996; Buchs 2003; Roo-Zielińska 2004).

Organic farming is still developing in Poland. At the end of 2013, there were more than 27,000 organic farms whose combined area was over 660,000 ha (GIJHARS 2011, 2012). According to Waszewska (2014), as many as 430 organic farmers were located in the Kujawy-Pomerania Province (for comparison, 340 farms in 2010). Environmental monitoring and cultivation according ecological methods are necessary on organic farms, because they directly affect the species diversity.

\section{Matherial and methods}

\subsection{Study sites}

The research was carried out in 3 organic farms in the Kujawy-Pomerania Province (Fig. 1):

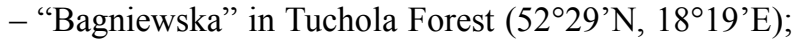




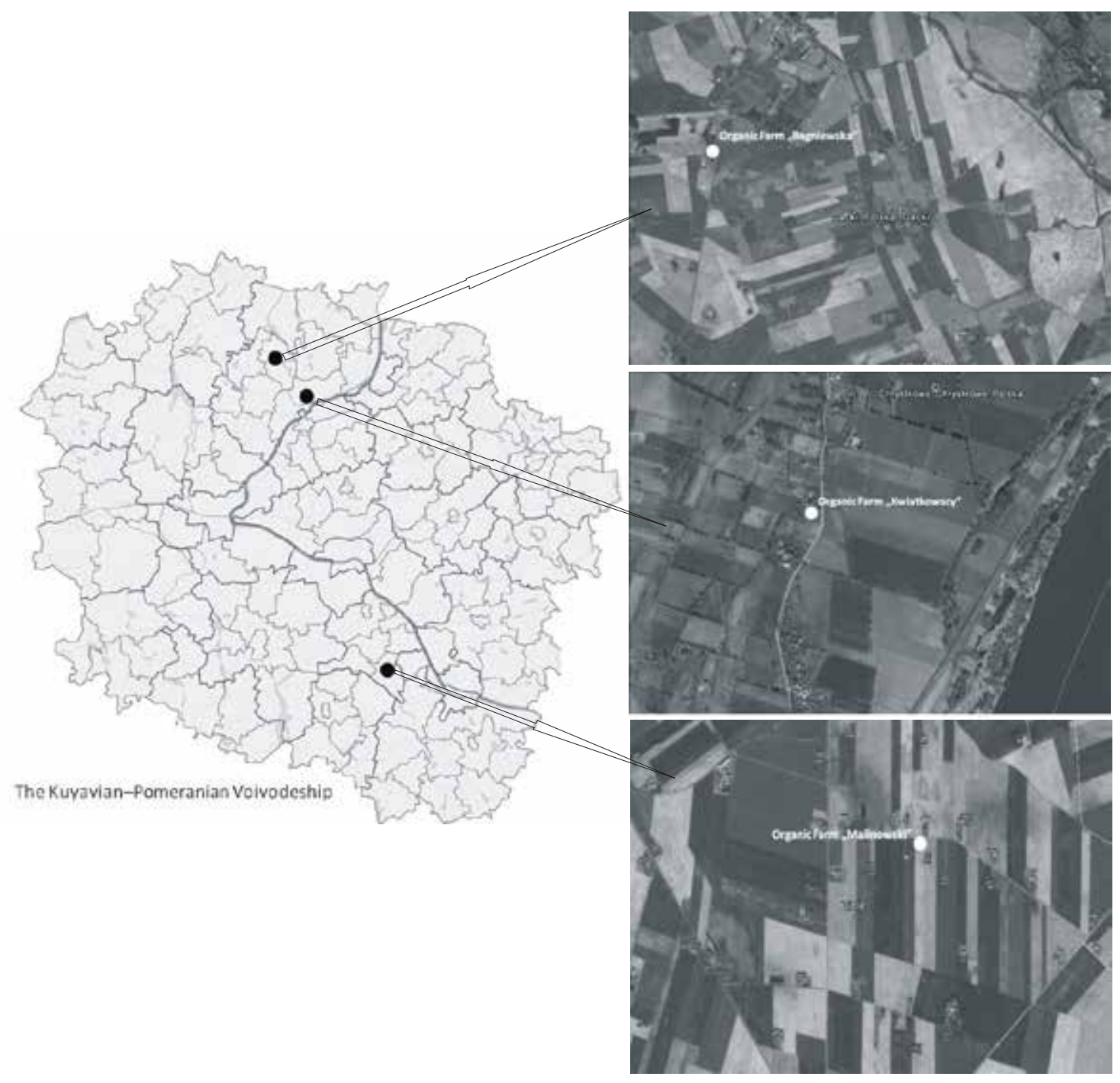

Figure 1. Location of the studied organic farms in the Kujawy-Pomerania Province (originally from: https//:maps.google.pl)

- "Malinowski”" in Kujawy (52॰42’N, 1850’E);

- "Kwiatkowscy" in the Lower Vistula Valley $\left(53^{\circ} 19^{\prime} \mathrm{N}\right.$, $\left.18^{\circ} 19^{\prime} \mathrm{E}\right)$.

Samples were taken from 5 habitats: a winter grain field, a pasture, a meadow, an orchard and buffer strips (Table 1).

\subsection{Sampling}

In 2011 samples of $50 \mathrm{~cm}^{3}$ volume and $17 \mathrm{~cm}^{2}$ surface were collected. Ten replicate samples were taken from 3 layers (one layer of a grass and lower parts of plants and two layers of soil) in 2 seasons (spring and autumn). In total, 780 samples were gathered. Mites from the samples were extracted in Tullgren funnels for 14 days, conserved in $75 \%$ ethyl alcohol. Then, all mites were determined to genus and oribatid mites also to species, including the juve- nile stages. The names of oribatis mites follow Weigmann (2006). In total, 8,980 mites were investigated, including 6,090 oribatid mites. Populations of oribatid species were characterized with abundance $A$ and dominance $D$ indices - the percentage share of the population of a particular species in grouping, species constancy $C$ - the percentage share of the samples in which a particular species was detected to the total number of samples while mite communities were compared with the Shannon index $H^{\prime}$ (Bieri et al. 1978; Górny \& Grüm 1981; Odum 1982), total abundance, and number of species.

\subsection{Statistical analysis}

All data were statistically analyzed with Statistica 10.0 (Statistica ver. 10.0, Statsoft) (Stanisz 2006a, b). The compliance with normal distribution was tested with the Kol- 
Table 1. Characteristics of studied organic farms

\begin{tabular}{|l|c|c|c|}
\hline $\begin{array}{c}\text { Charactristics of studied } \\
\text { organic farms }\end{array}$ & $\begin{array}{c}\text { Organic Farm ”Bagniewska" } \\
\text { (Tuchola Forest) }\end{array}$ & $\begin{array}{c}\text { Organic Farm ”Malinowski” } \\
\text { (Kujawy) }\end{array}$ & $\begin{array}{c}\text { Organic Farm "Kwiatkowscy” } \\
\text { (the Lower Vistula Valley) }\end{array}$ \\
\hline Total area & 14.9 ha & 6.8 ha & 7.4 ha \\
\hline \multicolumn{2}{|c|}{ Type of cultivation (ha) } \\
\hline Monoculture cereals & 7.8 & 2.0 & 2.6 \\
\hline Root crops & 1.7 & 0 & 0.5 \\
\hline Legumes & 2.0 & 2.5 & 0 \\
\hline Permanent grasslands & 1.0 & 1.5 & 3.0 \\
\hline Buffer strips & 0.9 & 0.5 & 0.3 \\
\hline Other & 1.5 & 0.3 & 1.0 \\
\hline Soil $\mathrm{pH}$ & $5.2-7.2$ & $6.5-7.0$ & $6.0-7.0$ \\
\hline Soil quality classification & IV-V & III-IV & III-V \\
\hline
\end{tabular}

mogorov-Smirnov test and the homogeneity of variance, with the Levene's test. ANOVA rang Kruskal-Wallis test was used, and, in case of significant differences between the averages, multiple comparison tests of the average ranks were used. The level of significance for all statistical tests was accepted at $\alpha=0.05$.

\section{Results}

Generally, higher density of all Acari, as well as oribatid mites, was noticeable in the buffer strips, but the highest density of them was observed in a meadow of the organic farm "Malinowski" in Kujawy (Table 2).

In all studied organic farms combined, 14 species of oribatid mites were found while only three of them occurred everywhere. A total number of mites and Oribatida differed substantially in the analyzed habitats. Species richness of oribatid mites was the highest in a meadow and a pasture in the organic farm "Malinowski" (Kujawy) and also in a buffer strips in the organic farm "Bagniewska" (Tuchola Forest). Species richness of oribatid mites was high in buffer strips in the organic farm "Bagniewska" and "Kwiatkowscy", also in a meadow of the organic farm "Malinowski". The Shannon index of diversity was relatively high in a winter grain field in the organic farm "Kwiatkowscy". After oribatid mites, the most abundant in all studied habitats were predatory Mesostigmata. Abundance of Mesostigamta was between 0.5 and 5 thousands individuals per $\mathrm{m}^{2}$. Mesostigmata, like oribatid mites, were the most numerous in meadows and buffer strip. Other groups of mites - Actinedida, Acaridida and Tarsonemida occurred rarely in investigated organic farms. Significant differences were proved in studied habitats only for abundance of orbiatid mites.
The most abundant oribatid mite species were Tectocepheus velatus [Michael, 1880], Scheloribates laevigatus [C.L. Koch, 1835], Punctoribates punctum [C.L. Koch, 1839] and Eupelops occultus [C.L. Koch, 1835]. However, it must be emphasised that their densities in the studied habitats differed significantly. Tectocepheus velatus was the most abundant only in a meadow and buffer strips in the organic farm "Malinowski". In these two habitats $S$. laevigatus and E. occultus were also the most abundant. Relatively, many species of oribatid mites occurred numerously in an orchard in the organic farm "Kwiatkowscy". Remaining species of oribatid mites were observed only occasionally and were not abundant.

Tectocepheus velatus belonged to class of superdominants (Seniczak 1978) in the organic farm „Malinowski” in a winter grain field, a pasture and buffer strip and in the organic farm „Bagniewska”, but only in a winter grain field. Furthermore, Punctoribates punctum was a superdominant in a meadow and in an orchard in the organic farm „Bagniewska”, while S. laevigatus was it in buffer strip in the same organic farm. In the organic farm „Kwiatkowscy" $S$. laevigatus dominated in a meadow and an orchard, whereas $P$. punctum dominated also in winter grain field. Other species of oribatid mites belonged to class of eudominants or dominants (Table 4). The most abundant species achieved rather low constancy index $C$. It proved that there was an inconsiderable competition between species in studied habitats (Table 3 ). 
Table 2. Characteristics of mite communities from habitats of studied organic farms (B - "Bagniewska", K - "Kwiatkowscy", M - "Malinowski"): $A$ - mean abundance (thousands individuals per $\left.\mathrm{m}^{2}\right), S$ - number of species, $H$ '- Shannon index of diversity

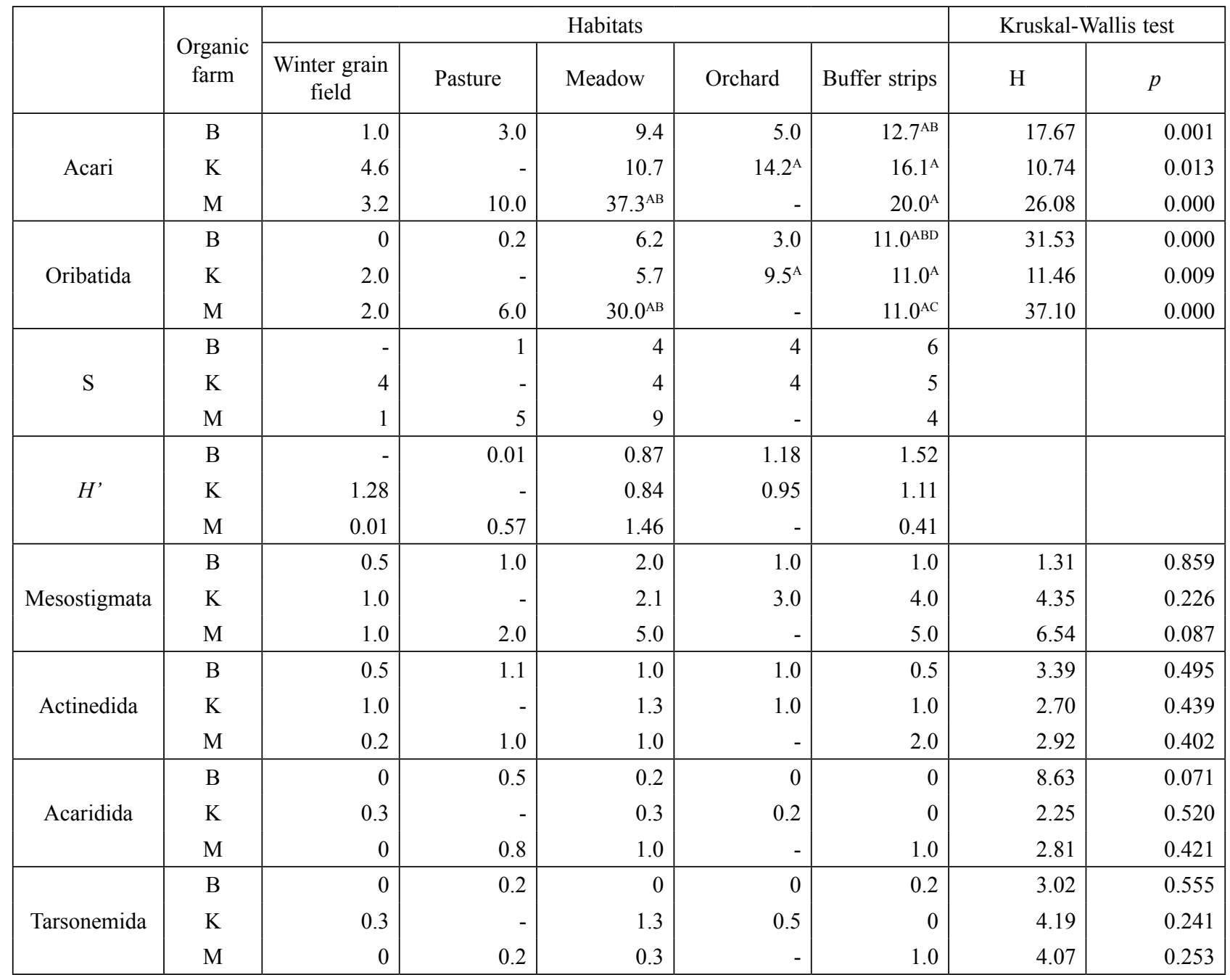

Significant differences $(\mathrm{p}<0.05)$ between the investigated habitats: ${ }^{\mathrm{A}}$ winter grain field and pasture, meadow, orchard, buffer strips; ${ }^{\mathrm{B}}$ pasture and meadow, orchard, buffer strips; ${ }^{\mathrm{C}}$ meadow and orchard, buffer strips; ${ }^{\mathrm{D}}$ orchard and buffer strips 
Table 3. Mean abundance $A$ (thousands individuals per $\mathrm{m}^{2}$ ) of oribatid mite communities from habitats of studied organic farms (B - "Bagniewska", K - "Kwiatkowscy", M - "Malinowski")

\begin{tabular}{|c|c|c|c|c|c|c|c|c|}
\hline \multirow{2}{*}{ Species } & \multirow{2}{*}{$\begin{array}{l}\text { Organic } \\
\text { farm }\end{array}$} & \multicolumn{5}{|c|}{ Habitats } & \multicolumn{2}{|c|}{$\begin{array}{l}\text { ANOVA rang } \\
\text { Kruskal-Wallis }\end{array}$} \\
\hline & & $\begin{array}{l}\text { Winter } \\
\text { grain field }\end{array}$ & Pasture & Meadow & Orchard & $\begin{array}{l}\text { Buffer } \\
\text { strips }\end{array}$ & $\mathrm{H}$ & $p$ \\
\hline \multirow{3}{*}{$\begin{array}{l}\text { Tectocepheus velatus } \\
\text { [Michael, 1880] }\end{array}$} & B & 0 & 0.2 & 1.0 & 0.4 & $2.0^{\mathrm{AB}}$ & 14.41 & 0.006 \\
\hline & $\mathrm{K}$ & 0.5 & - & 0.2 & 0.5 & $4.0^{\mathrm{ACD}}$ & 16.90 & 0.001 \\
\hline & $\mathrm{M}$ & 2.0 & 5.0 & $11.0^{\mathrm{A}}$ & - & $10.0^{\mathrm{A}}$ & 22.60 & 0.000 \\
\hline \multirow{3}{*}{$\begin{array}{l}\text { Scheloribates laevigatus } \\
\text { [C.L. Koch, 1835] }\end{array}$} & $\mathrm{B}$ & 0 & 0 & 0.2 & 0 & $5.0^{\mathrm{ABD}}$ & 41.45 & 0.000 \\
\hline & $\mathrm{K}$ & 0.5 & - & 4.0 & $6.0^{\mathrm{A}}$ & $0.8^{\mathrm{D}}$ & 22.42 & 0.000 \\
\hline & $\mathrm{M}$ & 0 & 0.3 & $9.0^{\mathrm{AB}}$ & - & $0.2^{\mathrm{C}}$ & 30.79 & 0.000 \\
\hline \multirow{3}{*}{$\begin{array}{l}\text { Punctoribates punctum } \\
\text { [C.L. Koch, 1839] }\end{array}$} & $\mathrm{B}$ & 0 & 0 & $4.0^{\mathrm{AB}}$ & 1.2 & 0 & 14.42 & 0.006 \\
\hline & $\mathrm{K}$ & 0.8 & - & 1.0 & 2.0 & $4.0^{\mathrm{ABC}}$ & 8.79 & 0.032 \\
\hline & $\mathrm{M}$ & 0 & 0.3 & 1.0 & - & 0.3 & 3.85 & 0.277 \\
\hline \multirow{3}{*}{$\begin{array}{l}\text { Eupelops occultus } \\
\text { [C.L. Koch, 1835] }\end{array}$} & $\mathrm{B}$ & 0 & 0 & 0 & 0 & 0 & - & - \\
\hline & $\mathrm{K}$ & 0 & - & 0.5 & 1.0 & $2.0^{\mathrm{ACD}}$ & 10.94 & 0.012 \\
\hline & $\mathrm{M}$ & 0 & 0 & $6.0^{\mathrm{A}}$ & - & 0 & 15.38 & 0.002 \\
\hline \multirow{3}{*}{$\begin{array}{l}\text { Trichoribates novus } \\
\text { [Sellincki, 1928] }\end{array}$} & $\mathrm{B}$ & 0 & 0 & 1.0 & 0.2 & 1.0 & 4.11 & 0.391 \\
\hline & $\mathrm{K}$ & 0 & - & 0 & 0 & 0 & - & - \\
\hline & $\mathrm{M}$ & 0 & 0 & 0.3 & - & 0 & 6.04 & 0.109 \\
\hline \multirow{3}{*}{$\begin{array}{l}\text { Liebstadia similis } \\
\text { [Michael, 1888] }\end{array}$} & $\mathrm{B}$ & 0 & 0 & 0 & $1.2^{\mathrm{A}}$ & $1.0^{\mathrm{ABC}}$ & 13.65 & 0.008 \\
\hline & $\mathrm{K}$ & 0 & - & 0 & 0 & 0 & - & - \\
\hline & $\mathrm{M}$ & 0 & 0 & 0 & - & 0 & - & - \\
\hline \multirow{3}{*}{$\begin{array}{l}\text { Trimalaconothrus maior } \\
\text { [Berlese, 1910] }\end{array}$} & $\mathrm{B}$ & 0 & 0 & 0 & 0 & 1.0 & 8.04 & 0.09 \\
\hline & $\mathrm{K}$ & 0 & - & 0 & 0 & 0 & - & - \\
\hline & $M$ & 0 & 0 & 0.3 & - & 0 & 3.00 & 0.391 \\
\hline \multirow{3}{*}{$\begin{array}{l}\text { Galumna lanceata } \\
\text { [Oudemans, 1900] }\end{array}$} & $\mathrm{B}$ & 0 & 0 & 0 & 0 & 1.0 & 8.04 & 0.09 \\
\hline & $\mathrm{K}$ & 0 & - & 0 & 0 & 0 & - & 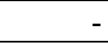 \\
\hline & $\mathrm{M}$ & 0 & 0 & 0 & - & 0 & - & - \\
\hline \multirow{3}{*}{$\begin{array}{l}\text { Hypochthonius rufulus } \\
\text { [C.L. Koch, 1835] }\end{array}$} & $\mathrm{B}$ & 0 & 0 & 0 & 0 & 0 & - & - \\
\hline & $\mathrm{K}$ & 0 & - & 0 & 0 & 0 & - & - \\
\hline & $\mathrm{M}$ & 0 & 0 & 0 & - & 0.5 & 6.04 & 0.109 \\
\hline \multirow{3}{*}{$\begin{array}{l}\text { Rhysotritia duplicata } \\
\text { [Grandjean, 1953] }\end{array}$} & $\mathrm{B}$ & 0 & 0 & 0 & 0 & 0 & - & - \\
\hline & $\mathrm{K}$ & 0 & - & 0 & 0 & 0.2 & 3.00 & 0.391 \\
\hline & $\mathrm{M}$ & 0 & 0.2 & 0 & - & 0 & 3.00 & 0.391 \\
\hline \multirow{3}{*}{$\begin{array}{l}\text { Scheloribates latipes } \\
\text { [C.L. Koch, 1844] }\end{array}$} & $\mathrm{B}$ & 0 & 0 & 0 & 0 & 0 & - & - \\
\hline & $\mathrm{K}$ & 0.2 & - & 0 & 0 & 0 & 3.00 & 0.391 \\
\hline & $\mathrm{M}$ & 0 & 0 & 2.0 & - & 0 & 3.00 & 0.391 \\
\hline \multirow{3}{*}{$\begin{array}{l}\text { Oppiella nova } \\
\text { [Oudemans, 1902] }\end{array}$} & $\mathrm{B}$ & 0 & 0 & 0 & 0 & 0 & - & - \\
\hline & $\mathrm{K}$ & 0 & - & 0 & 0 & 0 & - & - \\
\hline & $M$ & 0 & 0.2 & 0 & - & 0 & 3.00 & 0.391 \\
\hline \multirow{3}{*}{$\begin{array}{l}\text { Oribatula tibialis } \\
\text { [Nicolet, 1855] }\end{array}$} & B & 0 & 0 & 0 & 0 & 0 & - & - \\
\hline & $\mathrm{K}$ & 0 & - & 0 & 0 & 0 & - & - \\
\hline & $\mathrm{M}$ & 0 & 0 & 0.2 & - & 0 & 3.00 & 0.391 \\
\hline \multirow{3}{*}{$\begin{array}{l}\text { Scutovertex sculptus } \\
\text { [Michael, 1879] }\end{array}$} & $\mathrm{B}$ & 0 & 0 & 0 & 0 & 0 & - & - \\
\hline & $\mathrm{K}$ & 0 & - & 0 & 0 & 0 & - & 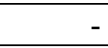 \\
\hline & $\mathrm{M}$ & 0 & 0 & 0.2 & - & 0 & 3.00 & 0.391 \\
\hline
\end{tabular}

Significant differences $(\mathrm{p}<0.05)$ between the investigated habitats: ${ }^{\mathrm{A}}$ winter grain field and pasture, meadow, orchard, buffer strips; ${ }^{\mathrm{B}}$ pasture and meadow, orchard, buffer strips; ${ }^{\mathrm{C}}$ meadow and orchard, buffer strips; ${ }^{\mathrm{D}}$ orchard and buffer strips 
Table 4. Characteristics of oribatid mite communities from habitats of studied organic farms (B - "Bagniewska", K - "Kwiatkowscy", $\mathrm{M}$ - "Malinowski"): $D$ - dominance in $\%$ (species $>2$ ) and $C$ - species constancy (\%)

\begin{tabular}{|c|c|c|c|c|c|c|}
\hline \multirow{2}{*}{ Species } & \multirow{2}{*}{ Characteristics } & \multicolumn{5}{|c|}{ Habitats } \\
\hline & & Winter grain field & Pasture & Meadow & Orchard & Buffer strips \\
\hline \multicolumn{7}{|c|}{ Organic Farm "Bagniewska" } \\
\hline \multirow{2}{*}{ Tectocepheus velatus } & $D$ & 0 & 100 & 14.29 & 15.79 & 16.92 \\
\hline & $C$ & 0 & 2.5 & 10 & 5 & 20 \\
\hline \multirow{2}{*}{ Scheloribates laevigatus } & $D$ & 0 & 0 & 2.86 & 0 & 49.21 \\
\hline & $C$ & 0 & 0 & 2.5 & 0 & 27.5 \\
\hline \multirow{2}{*}{ Punctoribates punctum } & $D$ & 0 & 0 & 71.43 & 42.11 & 0 \\
\hline & $C$ & 0 & 0 & 12.5 & 10 & 0 \\
\hline \multirow{2}{*}{ Trichoribates novus } & $D$ & 0 & 0 & 11.43 & 5.26 & 6.15 \\
\hline & $C$ & 0 & 0 & 5 & 2.5 & 5 \\
\hline \multirow{2}{*}{ Liebstadia similis } & $D$ & 0 & 0 & 0 & 36.84 & 10.77 \\
\hline & $C$ & 0 & 0 & 0 & 7.5 & 12.5 \\
\hline \multirow{2}{*}{ Trimalaconothrus maior } & $D$ & 0 & 0 & 0 & 0 & 9.23 \\
\hline & $\mathrm{C}$ & 0 & 0 & 0 & 0 & 5.0 \\
\hline \multirow{2}{*}{ Galumna lanceata } & $D$ & 0 & 0 & 0 & 0 & 10.77 \\
\hline & $C$ & 0 & 0 & 0 & 0 & 5.0 \\
\hline \multicolumn{7}{|c|}{ Organic Farm "Kwiatkowscy" } \\
\hline \multirow{2}{*}{ Tectocepheus velatus } & $D$ & 28.57 & - & 3.03 & 5.17 & 39.73 \\
\hline & $C$ & 2.5 & - & 2.5 & 7.5 & 25.0 \\
\hline \multirow{2}{*}{ Scheloribates laevigatus } & $D$ & 14.29 & - & 72.73 & 67.24 & 0 \\
\hline & $C$ & 2.5 & - & 22.5 & 30.0 & 0 \\
\hline \multirow{2}{*}{ Punctoribates punctum } & $D$ & 42.86 & - & 15.15 & 18.97 & 39.73 \\
\hline & $C$ & 5.0 & - & 10 & 7.5 & 25.0 \\
\hline \multirow{2}{*}{ Eupelops occultus } & $D$ & 0 & - & 9.09 & 8.62 & 19.18 \\
\hline & $C$ & 0 & - & 5.0 & 10.0 & 20.0 \\
\hline \multirow{2}{*}{ Rhysotritia duplicata } & $D$ & 0 & - & 0 & 0 & 1.37 \\
\hline & $C$ & 0 & - & 0 & 0 & 2.5 \\
\hline \multirow{2}{*}{ Scheloribates latipes } & $D$ & 28.57 & - & 0 & 0 & 0 \\
\hline & $\mathrm{C}$ & 2.5 & - & 0 & 0 & 0 \\
\hline \multicolumn{7}{|c|}{ Organic Farm "Malinowski" } \\
\hline \multirow{2}{*}{ Tectocepheus velatus } & $D$ & 100 & 86.84 & 37.24 & - & 90.41 \\
\hline & $C$ & 2.5 & 25.0 & 47.5 & - & 37.5 \\
\hline \multirow{2}{*}{ Scheloribates laevigatus } & $D$ & 0 & 2.63 & 31.63 & - & 1.37 \\
\hline & $C$ & 0 & 2.5 & 30.0 & - & 2.5 \\
\hline Punctoribates nunctum & $D$ & 0 & 5.26 & 3.06 & - & 4.11 \\
\hline Punctoribates punctum & $C$ & 0 & 2.5 & 7.5 & - & 2.5 \\
\hline Funglons occultus & $D$ & 0 & 0 & 18.88 & - & 0 \\
\hline Eupelops occultus & $C$ & 0 & 0 & 12.5 & - & 0 \\
\hline Trichoribates novus & $D$ & 0 & 0 & 1.02 & - & 0 \\
\hline Irlchorlbates novus & $C$ & 0 & 0 & 5.0 & - & 0 \\
\hline Hunohthonius rufulus & $D$ & 0 & 0 & 0 & - & 4.11 \\
\hline Hуросhthonlus rufulus & $C$ & 0 & 0 & 0 & - & 5.0 \\
\hline Rhycotritia dunlicata & $D$ & 0 & 2.63 & 0 & - & 0 \\
\hline Rhysotritıa duplicata & $C$ & 0 & 2.5 & 0 & - & 0 \\
\hline Scheloribates latines & $D$ & 0 & 0 & 6.63 & - & 0 \\
\hline Scheloribates latipes & $C$ & 0 & 0 & 2.5 & - & 0 \\
\hline & $D$ & 0 & 2.63 & 0 & - & 0 \\
\hline Oppiella nova & $C$ & 0 & 2.5 & 0 & - & 0 \\
\hline
\end{tabular}




\section{Discussion and conclusions}

Soil is a extraordinarily important part of all terrestrial habitats, it is available to maintain a biological production, determines and supports an increase, activity and existence of many species of animals. Apart of this, soil gets lots of natural and anthropogenic pollution and takes a big part in interactions with other environmental elements.

Biological activity of soil is very important for nutrient cycling and energy flow in terrestrial ecosystems, so soil determines production potential (Sławska 2007).

Meadows, orchards and fields are anthropogenic habitats. In these specific habitats usage, intensification of production, fertilization, physical and chemical properties of soil determine a soil quality. Organic farms are an alternative form for traditional farming, because there are many various law restrictions for organic farming about cultivation and livestock. Furthermore, health and high quality food in organic farms is produced. Organic farmers also cared about natural environment.

Oribatid mites live in meadows, forests, moors and because they usually occur abundant and high species constancy. Small sizes of oribatid mites, their big morphological differentiation and commonness of occurrence cause that lots of oribatid mites species could be used as bioindicators (Puchalski \& Prusinkiewicz 1975). Mites have different food preferences, but usually they are saprophagic organisms (Niedbała 1980; Boczek 2005) and greatly increase the breakdown of the organic matter (Graczyk 2010).

The highest abundance of mites (Acari) in every studied habitat was observed in the organic farm "Malinowski", whereas an abundance of mites was twice less in the organic farm "Bagniewska". Mites were the most abundant in a meadow in the organic farm "Malinowski" in Kujawy (30 thousands per $\mathrm{m}^{2}$ ). Graczyk (2010) obtained nearing results in an experiment made in a meadow, where mineral and organic fertilization weren't used. There was an inconsiderable abundance of orbatid mites in two remaining organic farms, probably because of worse properties of soil (Table 1) or grazing animals in meadows.

In the buffer strip, which constitute ecotone zones between fields, there was a high abundance of mites, especially oribatid mites. Number of mites was nearing in all analyzed organic farms, but the Shannon index of diversity was the highest there. These results are typical for ecotone zones, where usually species from adjacent habitats (meadows, fields etc.) occur (Seniczak et al. 2000). For example Tectocepheus velatus in the organic farm "Malinowski" was abundant in buffer strip, which were between meadow and pasture where this species was abundant too.

The less abundance of mites was observed in winter grain fields, where radical (for an ecosystem) agronomic processes are practiced. Many serious changes of soil en- vironment occurred in organic farms, despite of application of simplified technologies in cultivation (Twardowski et al. 2004), for example reducing tillage, because any agricultural intervention usually changes a number and activity of soil animals (Andersen 1999; Kladivko 2001).

Hülsmann and Wolters (1998) in their research proved a significant increase ( $>50 \%)$ of a numer of mites (Acari) in soil habitat in these organic farms, where a direct seeding method was used. Furthermore, an availability of organic matter there - necessary for saprophags - reduces mites populations.

If after crop harvest is not practiced, improper doses of organic fertilizers are used or removal of an excess of organic matter is practiced, an availability of nourishment for mites, especially oribatid mites, is reduced. It was proved in studied orchards. In the organic farm "Bagniewska" agricultural treatments, removal of fruits, leaves and moving the lawn were used, which result in decreasing of oribatid mites there. Furthermore, these agricultural agrotechniques were minimized on the organic farm "Kwiatkowscy" and, in consequence, the abundance of oribatid mites was much higher.

However, a low abundance of mites, which was noted in organic farms and in traditional farms, could affects positively on a quality of green fodder from meadows and pastures. The oribatid mites perform an important function in ecosystem as intermediate hosts of many various tapeworm species, for example from genus Moniezia and suborder Anoplocephalata (Rajski 1959; Niedbała 1980). Scheloribates laevigatus and Liebstadia similis settle mainly a layer of grass and lower parts of plants, so these species are eaten by grazing animals. In this way animals and, indirectly human, could become infected. Scheloribates laevigatus is considered as the most dangerous vector for tapeworms, because a commonness of this species in meadows and pastures. Therefore, an occurrence and an abundance of $S$. laevigatus is so important, especially in organic farms where active ingredients and measures to control parasitic infections aren't used

Other groups of Acari in the studied habitats were not abundant. However, lots of saprophages determine the abundance of Mesostigmata, predatory mites preying on oribatid mites. In the all studied habitats Mesostigmata was the most abundant group after Oribatida.

Mites could react differently on changes of agricultural methods. The experiment shows that an agriculture (especially a tillage), reduces a number of species and an abundance of oribatid mites, especially in crop fields because of small amounts of organic matter. Because of many law restrictions in the organic farming (obligated usage of special machines and to tools which protect soil; obligated fertilization by green manures, especially by legumes, compost etc.) negative influence of organic farming on soil environment is weaker than in traditional farming. Acaro- 
fauna develop intensively only if a post-harvest tillage is not used (Twardowski et al. 2004).

The following conclusions can be drawn on the basis of the conducted research:

1. Mites, especially oribatid mites, were most abundant in meadows and buffer strips of the studied organic farms. These results confirm that agrotechniques (even minimally invasive) reduce acarofauna in other habitats.

2. The highest significant differences occurred in abundance of mites between 3 habitats: winter grain field, pasture and meadow. There wasn't any significant difference between the organic farms in species composition and abundance of oribatid mites.

3. Species Tectocephaus velatus, Punctoribates punctum, Scheloribates laevigatus and Eupelops occultus were the most abundant. These eurytopic species of oribatid mites are usually observed in agroecosytems.

\section{References}

Andersen A., 1999, Plant protection in spring cereal production with reduced tillage. 2 . Pests and beneficials insects, Crop Protection 18: 651-657.

Behan-Pelletier V. M., 1999, Oribatid mite biodiversity in agroecosystems: role for bioindication, Agriculture, Ecosystems and Environment 74: 411-423.

Bieri M., Delucchi V. \& Lienhard Ch., 1978, Beschreibung von zwei Sonden zur Standarisierten Entnahme von Bodenproben für Untersuchungen an Mikroarthropoden, Mitt. Schweitz. Ent. Ges. 51: 327-330.

Boczek J., 2005, Podstawy anatomii, biologii i fizjologii roztoczy [Basic anatomy, biology and physiology of mites], [in:] B. Majkowska-Wojciechowska (ed.) Alergologia w praktyce, „Alergia na roztocze” [Effective allergology, “Allergy caused by mites”], Łódź 5: 31-39.

Boczek J. \& Błaszak Cz., 2005, Roztocze (Acari). Znaczenie w życiu i gospodarce człowieka [Mites (Acari. The importance to human life and economy], Wydawnictwo SGGW, Warszawa.

Buchs W., 2003, Biodiversity and agri-environmental indicators-general scopes and skills with special reference to the habitat level", Agriculture, Ecosystems \& Environmental, 98(1-3): 35-78.

GIJHARS (Główny Inspektorat Jakości Handlowej Artykułów Rolno Spożywczych [Trade Quality General Inspectorate of Agricultural and Food Products]), 2011, Raport o stanie rolnictwa ekologicznego w latach 2009-2010 [Report on ecological farming in 20092010], Warszawa.

GIJHARS (Główny Inspektorat Jakości Handlowej Artykułów Rolno Spożywczych [Trade Quality General Inspectorate of Agricultural and Food Products]), 2012, Raport o stanie rolnictwa ekologicznego w latach
2010-2011 [Report on ecological farming in 20092010], Warszawa.

Graczyk R., 2010, Wpływ nawożenia gnojowicą bydlęcą na akarofaunę glebową trwałego użytku zielonego, Rozprawa doktorska [Influence of cattle manure fertilization on the soil mite community of grasslands, PhD Thesis], Zakład Ekologii, Uniwersytetu Technologiczno-Rolniczego, Bydgoszcz.

Górny M. \& Grüm L., 1981, Metody stosowane w zoologii gleby [Methods used in soil zoology], PWN, Warszawa.

Hagvar S., 1994, Log-normal distribution of dominance as an indicator of stressed soil microarthropod communities, Acta Zoologica Fennica 195: 71-80.

Hülsmann A. \& Wolters V., 1998, The effects of different tillage practices on soil mites with particular reference to Oribatida, Applied Soil Ecology 9: 327-332.

Kladivko E. J., 2001, Tillage systems and soil ecology, Soil Till. Res. 61: 61-76.

Niedbała W., 1980, Mechowce - roztocze ekosytemów lądowch [Moss mites - mites of terrestrial ecosystems], PWN, Warszawa.

Odum E. P., 1982. Podstawy ekologii, wydanie trzecie [Fundamentals of Ecology, Third edition], PWRiL, Warszawa.

Puchalski T. \& Prusinkiewicz Z., 1975, Ekologiczne podstawy siedliskoznawstwa leśnego [Ecological basis of forest habitat typology], PWRiL, Warszawa.

Rajski A., 1959, Mechowce (Acari: Oribatei) jako żywiciele pośredni tasiemców (Cestodes: Anoplacephalata) w świecie literatury [Moss mites (Acari: Oribatei) as intermediate hosts of cestoids (Cestodes: Anoplacephalata) in the literature], Zeszyty Naukowe UAM 2: 163-192.

Roo-Zielińska E., 2004, Fitoindykacja jako narzędzie oceny środowiska fizycznogeograficznego [Phytoindication as a tool in the assessment of physical-geographical environment], IGiPZ PAN, Geographical studies 199, Warszawa.

Seniczak S., 1978, Stadia młodociane mechowców (Acari, Oribatei) jako istotny składnik zgrupowań tych roztoczy przetwarzających glebową substancję organiczną [Juvenile stages of moss mites (Acarina Oribatei) as an essentials component of agglomerations of these mittes transforming the organic matter of soil], Rozprawa habilitacyjna, Wydawnictwo UMK, Toruń.

Siepel H., 1996, The importance of unpredictable and short-term environmental extremes for biodiversity in oribatid mites, Biodiversity Letters 3: 26-34.

Sławska M., 2007, Skoczogonki Collembola Hexapoda i roztocze Acari Arahnida jako wskaźniki zdrowotności gleb leśnych" [Springtails Collembola Hexapoda and mites Acari Arahnida as indicators of forest soil health], Studia i Materiały Centrum Edukacji Przyrod- 
niczo-Leśnej [Studies and Materials of the Nature and Forest Education Center] R. 9, vol. 2/3(16).

Seniczak S., Klimek A. \& Kaczmarek S., 2000, Soil mites (Acari) of the ecotone between the scots pine forest and meadow in the forest landscape in Tuchola forest, [in:] A. Richling, J. Lechnio, E. Malinowska (eds.), Landscape ecology - theory and applicatons for practical purposes, Pułtusk School of Humanities, Poland, Warszawa: 249-262.

Stanisz A., 2006a, Przystępny kurs statystyki z zastosowaniem Statistica $P L$ na przykładach z medycyny, t. 1 . Statystyki podstawowe [Simple course of statistics with the use of Statistica PL based on examples from medicine, vol. 1. Basic statistics], StatSoft Polska, Kraków.

Stanisz A., 2006b, Przystępny kurs statystyki z zastosowaniem Statistica PL na przykładach z medycyny, t. 1 . Statystyki podstawowe [Simple course of statistics with the use of Statistica PL based on examples from medicine, vol. 2. Linear and nonlinear models], StatSoft Polska, Kraków.

Twardowski J., Smolis A. \& Kordas L., 2004, Wpływ różnych systemów uprawy roli na mezofaunę glebową. Badania wstępne [Effect of different agricultural production methods on soil mesofauna. Preliminary studies], Annales UMCS, Sec. E, 59(2): 817-824.

Weigmann G., 2006, Hornmilben (Oribatida). Die Tierwelt Deutschland und der angrenzenden Meeresteile, Goecke and Evers, Keltern, Deutschland.

Waszewska M., 2014, Producenci ekologiczni w Polsce w 2013 r. [Ecological producers in Poland in 2013], Wiedza i Jakość [Knowledge and Quality] 2(35): 1314. 